\title{
Pelatihan Teknik Pengajaran Vocabulary Berbasis Media Realia bagi Guru TK Bakti Sesela Kabupaten Lombok Barat
}

\author{
Tri Setianingsih*, Bq Zuhrotun Nafisah, Muhammad Arief Rizka, Sri Ariani, \\ I Made Permadi Utama, Siti Syafiatul Qomariyah, Imansyah \\ Universitas Pendidikan Mandalika \\ *Corresponding Author: trisetianingsih@ikipmataram.ac.id
}

\begin{abstract}
The purpose of this community service activity is to improve the understanding and ability of teachers at TK Bakti, Sesela, in applying vocabulary teaching techniques based on realia media. This is based on the lack of ability of teachers at TK Bakti in teaching vocabulary material to the children. The method used in the implementation of this service is participatory training with a duration of activities for one month as the scheduled basis. There were five students involved in this program. The results of this community service activity were the teachers at TK Bakti, Sesela had the understanding and ability to apply realia media for vocabulary teaching techniques. In addition, it can make the teachers easier to teach English to students by using objects in the surrounding environment without having to buy new media or toys that are expensive, so they can also save school expenses with limited funds. This community service activity also really helps to make the students easier to remember vocabulary in English as a basic for their ability to speak English in the future.
\end{abstract}

\begin{abstract}
Abstrak: Tujuan dari kegiatan pengabdian masyarakat ini adalah untuk meningkatkan pemahaman dan kemampuan para guru di TK Bakti Sesela dalam mengaplikasikan teknik pengajaran kosakata berbasis media realia. Hal ini didasari oleh kurangnya kemampuan guru di TK Bakti dalam mengajarkan materi kosakata kepada anak-anak. Metode yang digunakan dalam pelaksanaan pengabdian ini adalah pelatihan partisipatif dengan durasi kegiatan selama satu bulan sesuai jadwal. Ada lima mahasiswa yang terlibat dalam program ini. Hasil dari kegiatan pengabdian masyarakat ini adalah para guru di TK Bakti Sesela memiliki pemahaman dan kemampuan mengaplikasikan media realia untuk teknik pengajaran kosakata. Selain itu dapat memudahkan guru dalam mengajarkan bahasa Inggris kepada siswa dengan menggunakan benda-benda yang ada di lingkungan sekitar tanpa harus membeli media baru atau mainan yang mahal, sehingga dapat juga menghemat biaya sekolah dengan dana yang terbatas. Kegiatan pengabdian masyarakat ini juga sangat membantu siswa dalam mengingat kosakata bahasa Inggris sebagai dasar kemampuan berbahasa Inggris di masa depan.
\end{abstract}

\section{Article History:}

Received: 26-01-2021

Reviewed: 22-02-2021

Accepted: 04-03-2021

Published: 05-05-2021

Key Words:

Training,

Vocabulary, Realia

Media.
Sejarah Artikel:
Diterima: 26-01-2021
Direview: 22-02-2021
Disetujui: 04-04-2021
Diterbitkan: 05-05-2021

Kata Kunci:

Pelatihan, Vocabulary, Media Relia.

How to Cite: Setianingsih, T., Nafisah, B., Rizka, M., Ariani, S., Permadi Utama, I., Qomariyah, S., \& Imansyah, I. (2021). Pelatihan Teknik Pengajaran Vocabulary Berbasis Media Realia bagi Guru TK Bakti Sesela Kabupaten Lombok Barat. Jurnal Pengabdian UNDIKMA, 2(1), 64-72. doi:https://doi.org/10.33394/jpu.v2i1.3470

doi:https://doi.org/10.33394/jpu.v2i1.3470

This is an open-access article under the CC-BY-SA License.

\section{Pendahuluan}

Vocabulary atau kosakata merupakan landasan dasar dalam mempelajari bahasa Inggris. Dengan menghapal banyak vocabulary diharapkan ke depanya siswa akan lebih mudah dalam mempelajari bahasa Inggris baik listening, speaking, reading, ataupun writing 
dan secara tidak langsung akan memudahkan siswa dalam berkomunikasi dalam bahasa Inggris. Menurut beberapa ahli belajar vocabulary lebih mudah diberikankan pada anak usia dini seperti setingkat Taman Kanak-kanak (TK) dengan rata-rata usia 3-6 tahun karena pada usia tersebut kemampuan otak anak-anak lebih cepat menyerap dan mengingat materi apapun yang diberikan sesuai dengan usia mereka. Pada masa tersebut mereka mengalami masa yang disebut the golden age (masa peka). Golden age merupakan waktu paling tepat untuk memberikan bekal yang kuat kepada anak. Pada masa peka, kecepatan perkembangan otak anak selama hidupnya. Artinya, golden age merupakan masa yang sangat tepat untuk menggali segala potensi kecerdasan anak sebanyak-banyaknya (Suyanto, 2003).

Dalam masa perkembanganya anak-anak pada masa usia dini memerlukan berbagai layanan dan bantuan orang dewasa, dari kebutuhan jasmani sampai rohani. Di mana bentuk layanan tersebut diarahkan untuk memfasilitasi pertumbuhan sebagai peletakan dasar yang tepat bagi pertumbuhan dan perkembangan manusia seutuhnya, sehingga anak dapat tumbuh kembang secara optimal sesuai nilai, norma, serta harapan masyarakat. Dalam upaya mengoptimalkan segala kemampuan yang dimiliki anak usia dini yang berdasarkan prinsip PAUD, seharusnya setiap pendidikan anak usia dini memahami setiap tahapan pertumbuhan dan perkembangan karena segenap upaya yang dilakukannya harus berdasarkan pada tahapan tumbuh kembang anak agar mencapai hasil yang optimal.

Menurut Undang-Undang Republik Indonesia Nomor 20 tahun 2003 tentang sistem Pendidikan Nasional pada pasal 1 ayat 14 (Depdiknas, 2003) menyatakan bahwa pendidikan anak usia dini adalah suatu upaya pembinaan yang ditujukan kepada anak sejak lahir sampai dengan usia enam tahun, yang dilakukan melalui pemberian rangsangan pendidikan untuk membantu pertumbuhan dan perkembangan jasmani dan rohani, agar anak memiliki kesiapan dalam memasuki pendidikan lebih lanjut.

Santrock dan Yussen (dalam Solehuddin, 2000) berpendapat bahwa usia dini adalah masa yang penuh dengan kejadian - kejadian penting dan unik (a highly eventful and unique period of life) yang meletakkan dasar bagi kehidupan seseorang di masa dewasa. Sedangkan Hurlock (2012) mengemukakan bahwa lima tahun pertama anak merupakan peletak dasar bagi perkembangan selanjutnya. Perkembangan pada anak usia dini sangat penting dan berpengaruh pada perkembangan anak selanjutnya, sehingga pendidikan untuk anak usia dini harus disesuaikan dengan pertumbuhan dan perkembangan anak. Kegagalan pertumbuhan dan perkembangan pada masa ini akan berpengaruh pada masa- masa berikutnya.

Teknik pengajaran dengan menggunakan Realia atau yang disebut real objects merupakan media atau benda-benda yang bisa dilihat sehari-hari baik di rumah, di dalam kelas ataupun di halaman sekolah sehingga memudahkan bagi anak seusia TK untuk mengingatnya. Seperti dalam mengajarkan vocabulary pada anak TK Bakti di desa Sesela Kecamatan Gunungsari Kabupaten Lombok Barat, para guru di TK tersebut masih mengalami kesulitan dan sejauh ini belum memiliki pengalaman dan kemampuan yang cukup untuk mengajarkan vocabulary bagi anak.

Dalam hal ini, para guru TK Bakti harus inovatif dalam mengajarkan vocabulary dengan tehnik media Realia atau real objects. Dalam proses belajar mengajar harus diselingi dengan permainan dan candaan sehingga anak-anak tidak mudah merasa bosan belajar bahasa Inggris yang merupakan bahasa asing bagi mereka. Mereka juga harus mengajarkan dengan penuh kesabaran dan mengulang-ulang sampai anak-anak bisa dengan mudah mengingat vocabulary setiap benda dan mengucapkannya dengan benar. Para guru itu sendiri harus juga belajar vocabulary dan cara pelafalanya dengan benar sebelum mengajarkan kepada anak didiknya. 
Adapun tujuan dari kegiatan pengabdian kepada masyarakat ini adalah meningkatkan pemahaman dan kemampuan guru di TK Bakti Sesela dalam menerapkan teknik pengajaran vocabulary berbasis media relia sehingga dapat berimplikasi dalam memudahkan para siswa mengingat vocabulary ataupun kosa kata dalam bahasa Inggris sebagai landasan kemampuan mereka berbahasa Inggris di kemudian hari.

\section{Metode Pengabdian}

Metode dalam pelaksanaan program pengabdian kepada masyarakat ini adalah pelatihan partisipatif. Partisipatif dimaknai dengan melibatkan peserta pelatihan (Guru TK Bakti Sesela) dalam mempersiapkan kegiatan dan terlibat aktif dalam pelaksanaan pelatihan (Rizka \& Tamba, 2018: Huda et al, 2019, Setianingsih et al., 2020 \& Permana et al., 2020). Peserta pelatihan tehnik pengajaran vocabulary menggunakan media realia pada program pengabdian pada masyarakat ini adalah para guru dan kepala sekolah TK Bakti yang terletak di desa Sesela Kecamatan Gunungsari Kabupaten Lombok Barat. Kegiatan pelatihan tehnik pengajaran vocabulary menggunakan realia ini menggunakan 3 langkah yang meliputi presentasi, penugasan dan praktik. Ketiga langkah tersebut digunakan sebagai acuan dalam terlaksananya kegiatan pelatihan yang efektif dan efisien sehingga target dapat tercapai secara maksimal sesuai yang diharapkan. Kegitan pengabdian ini berlangsung selama 1 bulan secara terjadwal dengan melibatkan mahasiswa sebanyak 5 orang.

\section{Hasil Pengabdian dan Pembahasan}

Sasaran utama dari pengabdian pada masyarakat ini adalah guru TK Bakti Sesela dan peserta didik di TK tersebut yang terdiri dari 20 siswa TK A dan 30 siswa TK B. Kegiatan pengabdian masyarakat di TK Bakti Sesela secara umum telah berjalan dengan lancar. Para guru mendapatkan sharing ilmu dari tim pengabdian dengan menggunakan tehnik realia untuk mengajarkan vocabulary kepada anak didiknya menggunakan benda-benda yang ada di sekitar rumah, di dalam kelas dan di halamnan sekolah seperti peralatan makan: sendok, garpu, piring (dalam bahasa Inggris), di dalam kelas: buku, penghapus, pensil, pengggaris (dalam bahasa Inggris), di halaman sekolah seperti : pohon, bunga, jalan (dalam bahasa Inggris). Para guru merasa senang dan antuasias mendapat sharing ilmu dari tim pengabdian Universitas Pendidikan Mandalika dan siswa yang turut dalam kegiatan ini juga merasa senang diajarkan dengan menggunakan peralatan dan permainan yang bisa mereka temukan dan jumpai sehari-hari. Pelaksanaan program pengabdian kepada masyarakat ini dilaksanakan berbasis pelatihan dengan melalui tahapan kegiatan sebagai berikut:

\section{Tahap Persiapan}

Persiapan yang dilakukan sebelum memulai kegiatan pelatihan antara lain: (1) kordinasi dengan lembaga sekolah TK Bakti pada tanggal 17-18 Februari, (2) survey lokasi pelaksanaan pelatihan tanggal 24-25 Februari, (3) penyusunan materi pelatihan dan konsep kegiatan selama pelatihan tanggal 27-28 Februari, dan (4) penentuan narasumber pelatihan tanggal 2-3 Maret 2017. Pada saat tim mengadakan koordinasi dengan pihak sekolah, pihak sekolah merasa senang dan antusias dalam menerima kegiatan pelatihan ini. Pimpinan TK Bakti Sesela merasa jarang dikunjungi oleh pihak dari luar sekolah untuk mengadakan kegiatan seperti pengabdian yang dilaksanakan oleh tim dari Universitas Pendidikan Mandalika ini.

\section{Tahap Pelaksanaan Kegiatan}

Pelaksanaan program pengabdian ini dilaksanakan dalam kurun waktu satu bulan yakni dimulai 15 Maret-04 April 2019. 
Tabel 1. Struktur Kegiatan dan Pemateri Pelatihan

\begin{tabular}{|c|c|c|c|c|}
\hline No & Waktu & Jam & Kegiatan & Instruktur \\
\hline 1 & Pertemua I & $08.00-10.00$ & $\begin{array}{l}\text { Pelatihan dengan } \\
\text { memberikan materi } \\
\text { (vocabulary/kosakata) } \\
\text { yang berkaitan dengan } \\
\text { nama-nama benda di } \\
\text { dalam dan luar kelas }\end{array}$ & Sri Ariani, M.Pd \\
\hline 2 & Pertemua II & $08.00-10.00$ & $\begin{array}{l}\text { Pelatihan Pengajaran } \\
\text { vocabulary dengan } \\
\text { menggunakan tehnik } \\
\text { Realia }\end{array}$ & $\begin{array}{l}\text { Tri Setianingsih,S.S., } \\
\text { M.Pd }\end{array}$ \\
\hline 3 & Pertemua III & $08.00-10.00$ & $\begin{array}{l}\text { Pelatihan pengajaran } \\
\text { vocabulary } \\
\text { menggunakan tehnik } \\
\text { Realia dalam bentuk } \\
\text { diskusi untuk } \\
\text { merealisasikan poin } 1 \\
\text { dan } 2\end{array}$ & $\begin{array}{l}\text { Nanang Sugianto, } \\
\text { M.Pd. dan } \\
\text { Ahmad Hanan, M.Pd. }\end{array}$ \\
\hline 4 & Pertemua IV & $08.00-10.00$ & $\begin{array}{l}\text { Pelatihan pengajaran } \\
\text { vocabulary } \\
\text { menggunakan tehnik } \\
\text { Realia dalam bentuk } \\
\text { conversation untuk } \\
\text { merealisasikan poin } 1 \\
\text { dan } 2\end{array}$ & $\begin{array}{l}\text { Baiq Nafisah, M.A. } \\
\text { dan Terasne M.Pd. }\end{array}$ \\
\hline 5 & Pertemua V & $08.00-10.00$ & $\begin{array}{l}\text { Evaluasi bersama atas } \\
\text { keterlaksanaan poin 1-4 }\end{array}$ & $\begin{array}{l}\text { Muhammad Arief } \\
\text { Rizka dan I Made } \\
\text { Permadi Utama, } \\
\text { M.Pd }\end{array}$ \\
\hline
\end{tabular}

Materi pelatihan ini disusun berdasarkan hasil dari analisis kebutuhan dan diskusi secara langsung dengan para guru sebelum pelatihan dimulai yang disesuaikan dengan kebutuhan para guru dan siswa secara langsung seperti vocabulary yang sesuai untuk anak TK, alat-alat yang digunakan, dan cara mengajarkan. Modul Panduan tersebut meliputi:

\section{Konsep Realia}

Realia merupakan suatu benda, obyek nyata ataupun kegiatan sehari-hari yang digunakan sebagai media pembelajaran di dalam kelas. Realia pertama digunakan pada akhir abad ke 19 masehi dan masih digunakan hingga saat ini kebanyakan oleh guru bahasa asing seperti bahasa Inggris di Indonesia. Di Indonesia Realia bisa digunakan untuk mengajar vocabulary (kosakata) sehingga memudahkan siswa untuk memngingat kosakata tersebut.

\section{Kelebihan dan Kekurangan Realia}

Anak-anak PAUD ataupun TK biasanya cepat merasa bosan dan jenuh di dalam kelas maka guru harus menggunakan trik, strategi ataupun media yang membuat kegiatan belajar mengajar di dalam kelas menjadi lebih menyenangkan. Apalagi belajar bahasa Inggris yang masih merupakan bahhasa asing di Indonesia. Mereka biasanya malas-malasan dan tidak bersemangat karena dianggap sulit dihapalkan dan di pahami. Pada dasarnya anak-anak lebih 
mudah memahami apa yang mereka dengar, apa yang mereka lihat dan apa yang mereka lakukan sehari-hari. Hal tersebut merupakan prinsip dasar dan kelebihan penggunaan strategi ataupun media Realia. Adapun kekurangan dari strategi penggunaan media Realia yakni guru bahasa Inggris harus bersikap aktif dan reaktif dalam menyiapkan bahan-bahan ataupun media seperti poster binatang, buah-buahan ataupun benda-benda yang ada di sekitar kita, bisa juga berbentuk permainan dari plastik yang berbetuk buah-buahan, ataupun benda-benda yang biasa dipergunakan sehari-hari seperti buku, pensil, tas dsb. Cara Mengajar Menggunakan Media Realia: (a) Guru bisa menggunakan poster gambar buah-buahan, binatang, benda-benda yang ada di sekitar kemudian menyebutkan kata dalam bahasa Indonesia dan kemudian dalam bahasa Inggris. (b) Siswa menceritakan kembali dongeng sederhana yang diceritakan oleh guru. (c) Siswa diperbolehkan bermain kata-kata seperti tebak-tebakan kata. (d) Contoh: p-p-l-e-a disusun menjadi apple. (e) Siswa dapat menggambarkan ciri-ciri binatang atau benda yang ada di sekitarnya. Contoh: What Animal which can fly? Bird. (f) Latihan mendengarkan kata dalam bahasa Inggris dan siswa mengulanginya mengucapkan.

\section{Mengapa Vocabulary (Kosakata)}

Vocabulary (kosakata) merupakan salah satu aspek penting daalm mempelajari suatu bahasa. Setiap hari kita selalu berhubungan dengan benda-benda dan kejadian-kejadian yang kita alami dan kita ingin mengungkapkan suatu perasaan ataupun pikiran terhadap orang lain dengan menggunakan suatu bahasa. Untuk membentuk suatu kalimat kita membutuhkan beberapa kata. Kata-kata tersebut yang kita harus ketahui dan hapalkan baik cara penulisan ataupun cara pengucapan. Menurut Tailor (1991) semua benda di dunia ini harus mempunyai nama masing-masing untuk membedakan antara satu benda dengan benda lainnya, dan kita harus mengetahui nama benda dan kegunaanya. Dengan memahami berbagai kosa kata akan lebih memudahkan kita untuk berkomunikasi dengan orang lain. Edge (1993) juga mengatakan pentingnya mengetahui banyak kata dalam bahasa asing sehingga kita bisa lebih memahami dan mengerti makna dari suatu kata.

\section{Media Realia}

Berbagai media yang bisa digunakan dalam mengajar denga Realia seperti :

1). Poster

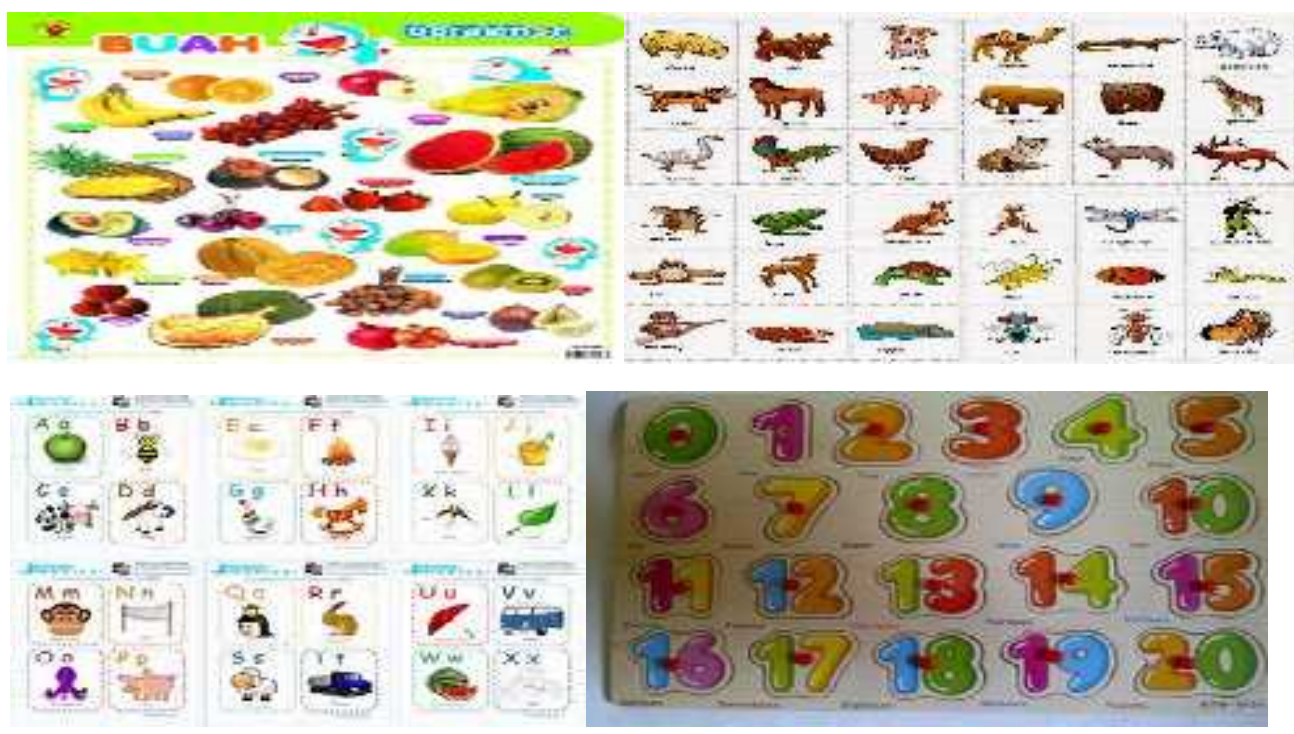

Gambar 1. Media Relia 
2). Membuat Permainan sendiri

Contoh: Mainan dari tutup botol untuk daya ingat anak

Tutup botol yang berwarna tentu bisa dijadikan mainan yang memiliki nilai positif pada anak. Anda bisa mengumpulkan beberapa tutup botol dengan warna yang berbeda atau ukuran yang berbeda. Lalu buatlah mainan seperti celengan dan berikan warna seperti gambar di bawah ini. Cara kerja mainan ini yakni dengan memasukkan tutup botol sesuai dengan lubang yang tersedia. Gunanya adalah untuk mengasah daya pikir dan ingat pada anak.Cara kerja mainan ini yakni dengan memasukkan tutup botol sesuai dengan lubang yang tersedia.

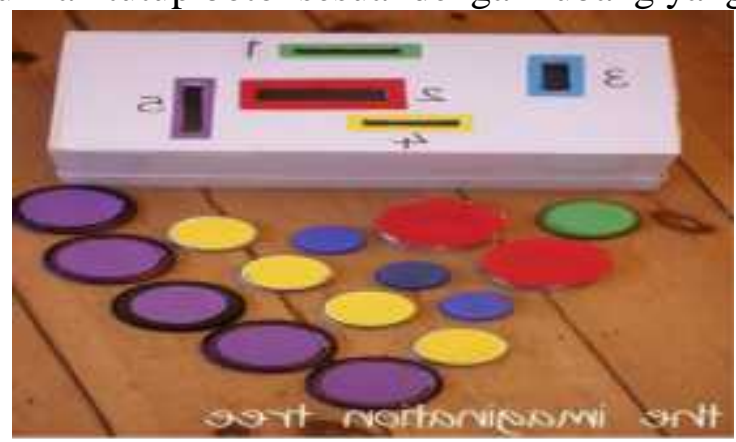

Gambar 2. Media Relia Tutup Botol

Gunanya adalah untuk mengasah daya pikir dan ingat pada anak.

3). Mainan dari Plastik Yang Banyak Dijual

4). Benda-benda yang ada di sekitar kita seperti sendok, garpu, piring, sikat gigi, tas, buku, pensil, penghapus, meja, kursi, tembok, guru, murid, pohon, bunga, jalan dll.
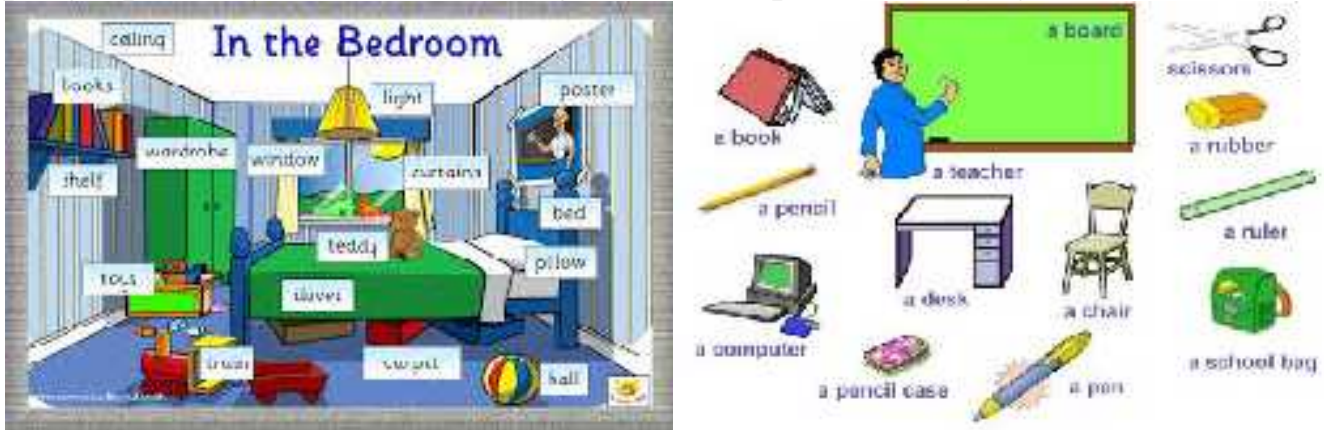

\section{Deskripsi Kegiatan}

Gambar 3. Media Relia Lingkungan Sekitar

a) Presentasi, yaitu penyajian materi berupa media pengajaran menggunakan realia secara langsung kepada peserta pelatihan oleh narasumber yang dilakukan oleh tim pengabdian secara bergantian agar para peserta yakni para guru TK Bakti dapat mengetahui dan menyerap gambaran umum tentang materi pelatihan secara jelas.

b) Praktek, yaitu memberikan kesempatan bagi para peserta yakni guru untuk memperaktikkan secara langsung hal-hal yang sudah diajarkan selama proses pelatihan berlangsung kepada anak didiknya adapun tentang praktek ini tetap diawasi oleh tim pengabdian agar tidak terjadi kesalahan ataupun hal-hal yang tidak diinginkan seperti kesalahan dalam hal menyebut benda ataupun cara mengajarkan vocabulary dengan .menggunakan realia.

c) Diskusi, yaitu memberikan kesempatan bagi para peserta untuk bertanya seputar materi yang telah di sampaikan sekiranya masih ada yang belum/kurang jelas sesuai dengan tema pelatihan tehnik pengajaran vocabulary menggunakan realia. 


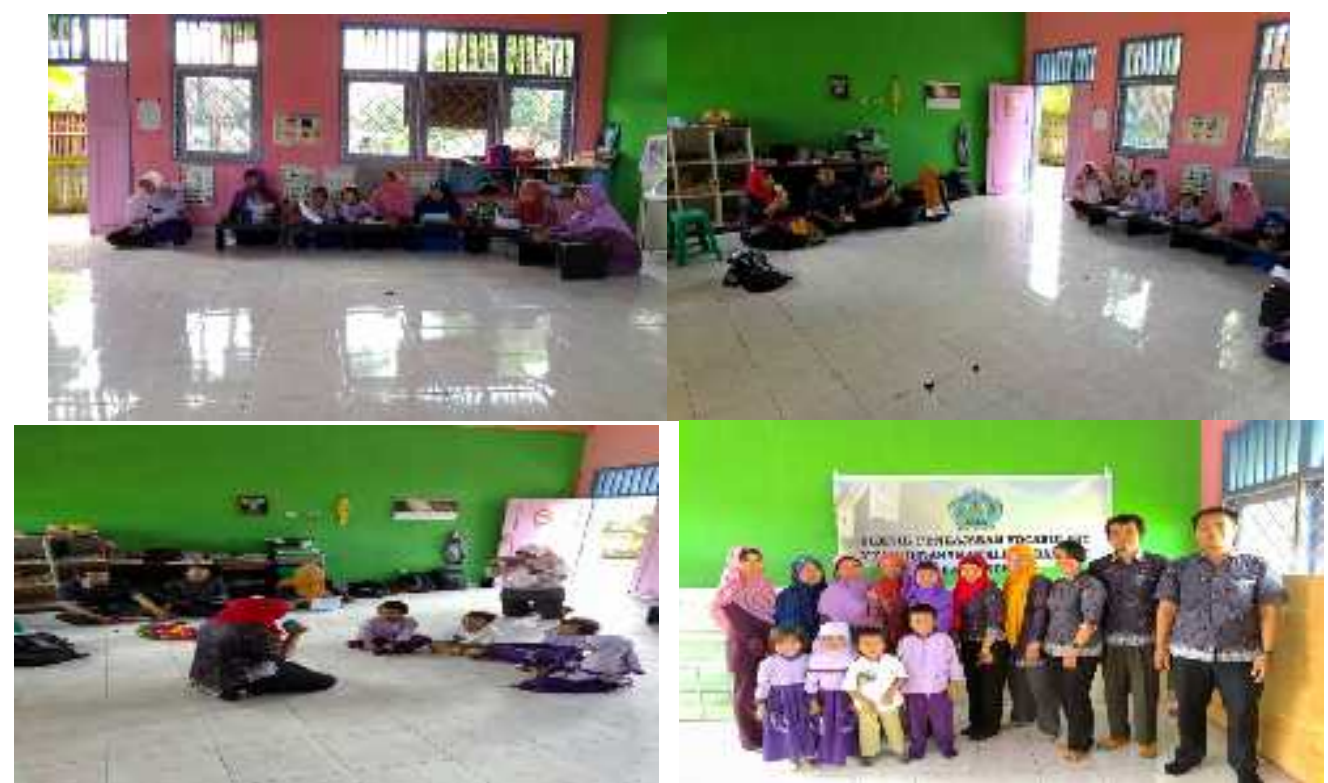

Gambar 4. Proses Pelatihan Teknik Pengajaran Vocabullary

\section{Evaluasi Kegiatan}

Setelah penyampaian materi dan pelaksanaan pengabdian, Tim PkM berupaya untuk melakukan evaluasi terhadap implementasi dari pelatihan yang diselenggarakan. Evaluasi ini bertujuan untuk mengetahui tingkat keberhasilan dari pelaksanaan kegiatan pelatihan yang dilakukan. Evaluasi kegiatan pelatihan fokusnya terdiri dari evaluasi proses dan produk (hasil) (Stufflebeam, 2003). Evaluasi proses dalam pelaksanaan pelatihan ini terkait dengan evaluasi tingkat partisipasi, respon (tanggapan) peserta, dan proses penyampaian materi pelatihan. Sedangkan evaluasi produk terkait dengan kemampuan peserta pelatihan dalam menguasasi materi dan dalam melakukan praktek evaluasi program berdasarkan mekanisme dan prosedur evaluasi program yang tepat.

\section{Evaluasi Proses}

Evaluasi proses ini berupaya untuk mengetahui tingkat partisipasi, respon, dan pemahaman terhadap materi pelatihan yang disampaikan kepada peserta pelatihan (para guru TK Bakti). Respon peserta terhadap kegiatan pelatihan ini menunjukkan dukungan yang positif dan memandang perlu untuk mengembangkan kegiatan sejenis yang dapat berkesinambungan. Terkait dengan respon peserta terhadap pelaksanaan kegiatan pelatihan ini, berikut visualisasi dari respon peserta setelah diberikan angket berisi tanggapan terhadap kegiatan pelatihan.

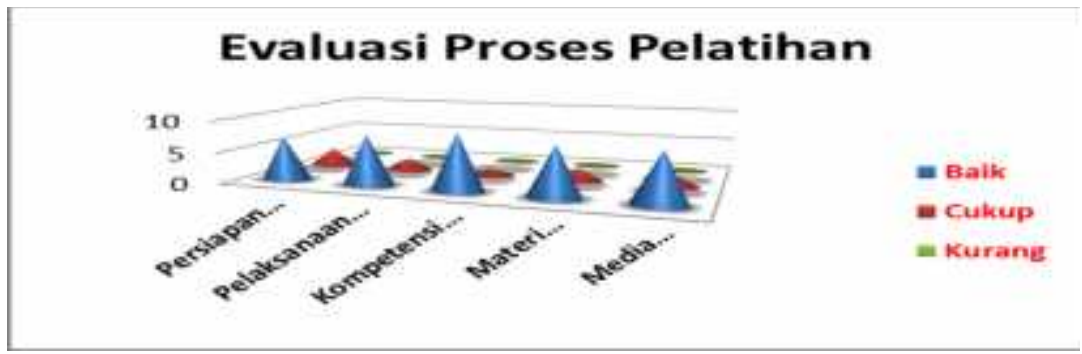

\section{Grafik 1. Respon Peserta Pelatihan}

Berdasarkan pada Grafik 1 diatas, dapat dimaknai bahwa secara umum respon peserta pelatihan (Guru TK Bakti) terhadap pelaksanan pelatihan ini berada pada kateori baik, hal ini terlihat dari data grafik yang menunjukkan bahwa pada aspek; (1) Persiapan Pelatihan, 
peserta menjawab $70 \%$ baik dan $30 \%$ cukup; (2) aspek Pelaksanaan Pelatihan, peserta menjawab 80\% Baik dan 20\% cukup; (3) aspek Kompetensi Pemateri, peserta pelatihan menjawab $90 \%$ baik dan hanya $10 \%$ cukup; (4) aspek Materi Pelatihan, peserta menjawab $80 \%$ baik dan $20 \%$ cukup; dan (5) aspek Media Pelatihan, peserta menjawab $80 \%$ baik dan $20 \%$ cukup.

\section{Evaluasi Hasil}

Pada aspek evaluasi hasil (produk) pelatihan ini, Tim PkM berupaya untuk malakukan evaluasi terkait dengan tingkat penguasaan peserta pelatihan baik dalam menguasai (mamahami) materi pelatihan maupun dalam kemampuan peserta untuk praktik penerapan teknik pengajaran vocabulary berbasis media relia. Terkait dengan evaluasi hasil kegiatan pelatihan ini, Tim PkM berupaya melakukan observasi (pengamatan) secara cermat dan memberikan penugasan praktik kerja (mandiri) secara langsung kepada peserta pelatihan untuk mengetahui penguasaan pemahaman materi dan praktiknya. Berikut visualisasi kemampuan penguasaan materi dan praktik peserta pelatihan.

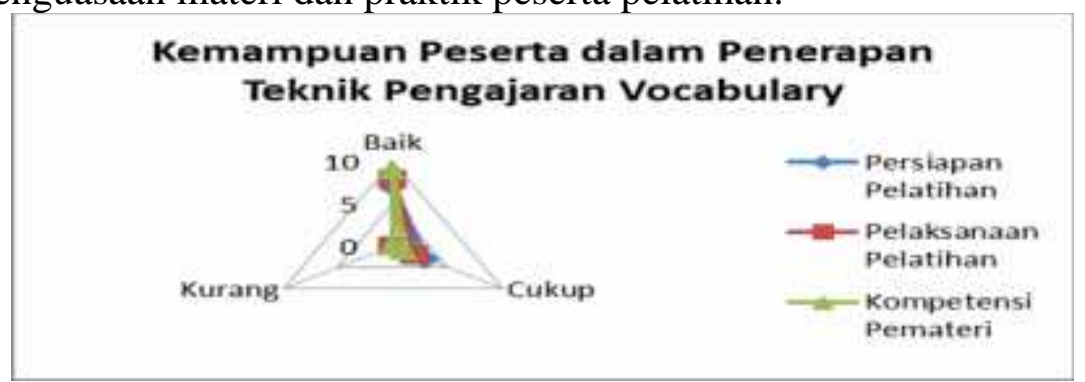

\section{Grafik 2. Kemampuan Peserta Pelatihan}

Berdasarkan pada data grafik 2 diatas, kemampuan peserta dalam; (1) aspek pemilihan materi menunjukkan bahwa sebanyak $90 \%$ peserta memahami dan menguasainya dan hanya $10 \%$ yang kurang menguasai (memahami); (2) aspek penerapan teknik pengajaran vocabulary berbasis media relia menunjukan bahwa sebanyak $80 \%$ peserta memahami dan menguasainya, sebanyak $10 \%$ peserta cukup menguasai, dan $10 \%$ kurang menguasai (memahami); dan (3) aspek penggunaan media relia menunjukkan bahwa sebanyak $70 \%$ peserta memahami dan menguasainya, sebanyak 20\% peserta cukup menguasasi, dan $10 \%$ kurang menguasai. Dari analisis hasil evaluasi terhadap kemampuan peserta pelatihan tersebut, khusus pada aspek penggunaan media relia perlu untuk mendapat perhatian kedepan disebabkan tidak semua peserta pelatihan yang memiliki tingkat pemahaman dan penguasaan terhadap materi tersebut. Sehingga pada aspek ini perlu dilakukan upaya penguatan berupa kegiatan pendampingan intensif yang berkesinambungan pasca pelatihan dilaksanakan. Mengacu pada indikator keberhasilan kegiatan pelatihan ini, secara umum pelaksanaan kegiatan pelatihan ini telah mencapai indikator keberhasilan yang telah ditentukan. Indikator keberhasilan dari pelaksanaan kegiatan pelatihan ini antara lain: (1) Peserta pelatihan aktif (partisipatif) dan bekerjasama dengan baik selama mengikuti kegiatan, hal ini dapat terlihat dari tingkat kehadiran peserta, aktivitas diskusi dan tanya jawab antara peserta dan pemateri yang dialogis. (2) Peserta pelatihan memahami materi-materi pelatihan, hal ini dapat diukur dari pencapaian kemampuan memahami materi-materi pelatihan oleh peserta yang berada dalam kategori menguasai.

\section{Kesimpulan}

Kesimpulan yang diperoleh dari hasil kegiatan pengabdian ini bahwa pelaksanaan kegiatan pengabdian kepada masyarakat ini secara umum telah terlaksana dengan baik, para guru TK 
Bakti Sesela sebagai peserta pelatihan telah memiliki pemahaman dan kemampuan untuk menerapkan teknik pengajaran vocabulary berbasis media relia. Selain itu dapat memudahkan para guru untuk mengajarkan bahasa Inggris kepada siswa dengan menggunakan bendabenda yang ada di lingkungan sekitarnya tanpa harus membeli media baru atau mainan yang harganya mahal sehingga dapat menghemat pengeluaran sekolah yang dananya terbatas. Kegiatan pengabdian masyarakat ini juga sangat membantu memudahkan para siswa mengingat vocabulary ataupun kosa kata dalam bahasa Inggris sebagai landasan kemampuan mereka berbahasa Inggris di kemudian hari.

\section{Saran}

Adapun saran yang disampaikan berdasarkan hasil kegiatan pengabdian ini adalah agar program pengabdian bagi guru-guru TK Bakti Sesela ini tetap ditindaklanjuti dengan melalui pendampingan informal secara terprogram dan diharapkan dapat diadakan setiap tahun ajaran dengan pengmbangan jangkauan peserta dari lembaga TK yang lainnya.

\section{Daftar Pustaka}

Depdiknas. (2003). UU Sistem Pendidikan Nasional. Jakarta: Depdiknas

Hurlock, E. B. (2012). Psikologi Perkembangan, Suatu Pendekatan Sepanjang Rentang Kehidupan (terjemahan). Jakarta: Erlangga.

Huda, K., Sarilah, S., \& Rizka, M. A. (2019). PELATIHAN PENINGKATAN KEMAMPUAN KOGNITIF ANAK MELALUI PENDEKATAN CONTEXTUAL TEACHING \& LEARNING DI TK DARUL MUHSININ KAB. LOMBOK TENGAH. Jurnal Pendidikan dan Pengabdian Masyarakat, 2(4). http://jurnalfkip.unram.ac.id/index.php/JPPM/article/view/1567

Solehuddin, (2000). Konsep Dasar Pendidikan Pra Sekolah. Bandung: UPI

Suyanto, S. (2003). Konsep Dasar Pendidikan Anak Usia Dini.Yogyakarta: UNY

Thornburry, Scott. (2002). How to Teach Vocabulary. Longman: Pearson.

Permana, D., Qomariyah, S., \& Rizka, M. (2020). Pelatihan Keterampilan Berkomunikasi Bahasa Inggris Bagi Pramusaji Kedai di Kawasan Wisata Aik Berik. Jurnal Pengabdian UNDIKMA: Jurnal Hasil Pengabdian dan Pemberdayaan Kepada Masyarakat, 1(1). doi:https://doi.org/10.33394/jpu.v1i1.2546

Rizka, M. A., \& Tamba, W. (2019). Pelatihan Evaluasi Program Pendidikan Nonformal Bagi Pengelola Pusat Kegiatan Belajar Masyarakat (PKBM) di Kecamatan Gunungsari Kabupaten Lombok Barat. Paradharma (Jurnal Aplikasi IPTEK), 2(1). DOI: http://dx.doi.org/10.36002/jpd.v2i1.561

Setianingsih, T., Qomariyah, S., Ariani, S., \& Suhaili, M. (2020). Pelatihan Penulisan Karya Tulis bagi Guru SMA Hang Tuah 3 Mataram. Jurnal Pengabdian UNDIKMA: Jurnal Hasil Pengabdian dan Pemberdayaan Kepada Masyarakat, 1(1). doi:https://doi.org/10.33394/jpu.v1i1.2549

Setianingsih, T., Qomariyah, S., Nafisah, B., Ariani, S., \& Rizka, M. (2020). Pelatihan Perintisan dan Manajemen Lembaga Bimbingan Belajar bagi Mahasiswa Undikma Sebagai Upaya Meningkatkan Jiwa Social Entrepreneurship. Jurnal Pengabdian UNDIKMA: Jurnal Hasil Pengabdian dan Pemberdayaan Kepada Masyarakat, 1(2), 128-132. doi:https://doi.org/10.33394/jpu.v1i2.2932

Stufflebeam. (2003). The CIPP Model for Evaluation. Portland, Oregon: Western Michigan University. 